\title{
Perception of Social Maturity Criteria, Self-perception and Value Orientations among Russian Millennials
}

\author{
Alexander M. Rikel \\ Lomonosov Moscow State University \\ 1 Leninskie Gory, Moscow, 119991, Russian Federation
}

\begin{abstract}
The difference between generations is becoming increasingly apparent in the modern world. These days, one can observe over and over again how the intergenerational transmission of values is violated, and the differences between generations are becoming more and more noticeable. A number of studies are focused on the features that distinguish modern generations from each other, the values of generations as well as the perception of these values both by a particular generation and members of cohorts interacting with it. Some researchers note that the modern young generation (the so-called 'Generation Y', 'Gen Y' or 'millennials'), in comparison with their parents (the so-called 'Generation X', 'Gen X'), is characterised by a rejection of previously accepted criteria for social maturity (which can be understood as compliance with a number of social-psychological standards). However, there are practically no studies addressing this topic. The article describes a quantitative and qualitative study conducted in three stages, which involved 349, 25 and 100 subjects respectively. At the first stage, the data of the Russian longitudinal monitoring survey (RLMS) of households conducted by HSE University were used and analysed; at the second stage, a series of semi-structured interviews was conducted on the topic of perception of social maturity; at the third stage, the values of generational cohorts were investigated using the Rokeach Value Survey (RVS) and the author's questionnaire, which makes it possible to assess the influence of the cultural context on the formation of values. Within the first (auxiliary) stage, the basic hypothesis was confirmed about the differences in the compliance with the social maturity criteria (age of marriage, presence of children in the family, financial independence) among the young (Y) and older (X) generations of modern Russians. As part of the second stage, the features of the perception of these differences were identified. And at the third stage, it was proposed to interpret the differences using the values identified in millennials and the features of the perception of these values by themselves and Gen Xers.
\end{abstract}

Key words: Generation Y, Generation X, values of generations, social maturity, criteria of social maturity

\section{Introduction}

Violation of the intergenerational transmission of values is increasingly becoming the subject of social-psychological research in Russia and abroad (Martsinkovskaya, Poleva, 2017; Pishchik, 2015; Rikel, 2019; Starchikova, 2012; Gil- 
leard, Higgs, 2005; Twenge, Campbell, 2009). 'Generations' can be considered as large social groups (Andreeva, 2001), and the social-psychological operationalisation of this term is based on K. Mannheim's classical understanding through the impact of the social and cultural context on age groups (Mannheim, 1997). In close examination, the problem of generations is analysed and popularised in most modern works by social psychologists, sociologists and cultural scientists. Scientists point to the factors that form generations, the grounds for distinguishing generations, the main characteristics inherent in members of one generation. Based on a combination of factors, various typologies of generations of varying degrees of popularity are proposed (Levada, 2011; Pishchik, 2015; Semenova, 2003; Strauss, Howe, 1991; etc.). As the basic features that distinguish modern generations from each other, scientists often highlight values and related features of mutual perception of generations based on the perception of these values (Pishchik, 2015; Shevchenko, 2013; Hershatter, Epstein, 2010; Lyons, Kuron, 2014; Lusk, 2007; Parry, Urwin, 2010).

Regardless of the specific names in various typologies, a number of Russian and foreign researchers note that the modern young generation (late 1980s-1990s), in comparison with their parents, is characterised by a rejection of previously accepted social maturity criteria (Ilyin, 2012; Martsinkovskaya, Poleva, 2017; Khriptovich, 2015; Arnett, 2000; Billari, Liefbroer 2010; Calcutt, 2010; Omelchenko, 2012).

Russian Gen Y members, born in 1985-2003 (this classification is conventionally accepted as the most popular within the framework of this study), were born during radical and controversial changes in the economic and political structure of our country. The values and features of this generation were determined by the economic and political factors (globalisation, the collapse of the USSR, liberalisation of public life) and the development of information technologies (Internet, social networks, etc.) (Radaev, 2019). Millennials are often characterised by high expectations, a trend towards fast and constant consumption and a desire to quickly achieve high career results and financial well-being (Khriptovich, 2015). At the same time, the instability of the political and economic situation in the country led to the desire of parents to protect them from various dangers, providing them with control and special care, so that some of the millennials turned out to be reluctant to go away from under the parental 'wing' (Rean, Shagalov, 2018). This can be illustrated by the fact that higher education is perceived by some millennials not as professional preparation for adulthood but as a continuation of the childhood period (Ilyin, 2012). This consideration allowed a number of authors, as we see it, to make an overly radical, not empirically confirmed conclusion about the personal immaturity, infantilism, and irresponsibility of millennials (Khriptovich, 2015).

It is the desire to test these categorical conclusion about the immaturity of millennials that formed the basis of our study. We understood maturity not as a characteristic of the features of human development at different age stages (Patturina, 2006) and not as a personality trait, but as a criterion for the compliance with social standards that existed in a number of previous generations prescribed by society for a certain age (Kon, 1999; Anisimov, Kireeva, 2010) (forming a family and learning the familial and parental social roles, beginning labour activity associated with financial independence). These criteria were analysed in the context of the Generation Y values as well as the perception of the millennials by the Gen 
Xers (born in 1964-1984), since the analysis of behavioural patterns without considering this perception and the value orientations that determine it seems incomplete.

\section{Methods}

The purpose of this study was to identify the features of the perception of social maturity criteria and values associated with this perception among the younger generation (Y), as well as the perception of these values by the older generation (X). The object of the study was Generation Y and the subject was the perception of values associated with social maturity criteria.

The study was conducted in three stages (the first and second stages in cooperation with A.V. Milyukhina, the third stage in cooperation with S.V. Dorenskaya). At the first (auxiliary) stage of the study the distinctive features of millennials were confirmed in the context of social maturity criteria. To achieve this, we used the cohort analysis method to analyse data obtained from the Russian Longitudinal Monitoring Survey (RLMS) (https://www.hse.ru/rlms/), which has been conducted by the National Research University Higher School of Economics (NRU HSE) annually since 1994, and highlight the issues characterising the indicated maturity criteria (related to having a family, children and gainful employment). The responses of twenty-year-old subjects born in 1974 (the so-called 'core' of Generation X) and in 1995 (the 'core' of Generation Y) were compared.

At the second (main) stage of the study, differences in the perception of these social maturity criteria between the older and younger generations were revealed. In order to accomplish this task, in-person semi-structured interviews were conducted based on an analysis of projective situations involving the concept of maturity.

Examples of situations. (1) "A couple - a man (aged 28) and a woman (aged 26) - live together for several years, rent an apartment, do not register their marriage, employed, frequent travellers, do not plan to have children in the next couple of years". (2) A woman (aged 27), works for a prestigious company, is receiving a second higher education, lives separately from her parents. She has some relationships but does not consider them seriously, is in search of a life partner. She spends her spare time attending various cultural events, theatres, clubs, and practising yoga.

The interviews contained the following questions: 1) Describe the person(s). How do you perceive him/her/them? What criteria do you follow when describing him/her/them in this way? What do you pay attention to in this situation? 2) What do you think are the reasons for this lifestyle? (3) What is your attitude to this lifestyle?

At the third (main) stage of the study, the values of Generation $\mathrm{Y}$ were studied with the help of (a) the Rokeach Value Survey; (b) the author's methodology, which makes it possible to reveal the peculiarities of the influence of the cultural context on the formation of generations and evaluate the perception of the generational values by representatives of older generations (in this case, Generation X). In particular, the Gen Xers were invited to answer the question "What values, in your opinion, are characteristic of millennials?" and to complete a number of sentence fragments (for example, "A typical millennial is convinced that...", "The meaning 
of the life for a millennial is...", etc.). This stage of the study was conducted to interpret the differences in perception and behaviour. Some of the results of this study are described separately (Rikel, Dorenskaya, 2017); here we use only data related to value problematics and associated social maturity criteria.

Samples. The first stage: 349 subjects: 159 subjects of the older generation X (born in 1974) and 190 subjects of the younger generation Y (born in 1995). The second stage: 25 subjects: 12 Gen Xers aged 42-49 and 13 millennials aged 22-25. The third stage: 100 subjects: 65 millennials (the average age $=23.2$ years) and 35 Gen Xers (the average age $=40.3$ years).

This particular age of the subjects was chosen according to the traditional analysis logic for intergenerational research of the so-called 'generation core', i.e. a group of people born in the middle of the generation cycle distinguished by sociologists. This approach, taking into account some criticisms regarding the study of the characteristics of generational cohorts, nevertheless, makes it possible to increase the internal and constructive validity of the results obtained by "clearing" the sample of subjects belonging to the borderline, so-called "echo-generations" (Becton et al., 2014; Costanza et al., 2012; Egri, Ralston, 2004; etc.).

Data processing methods. The data obtained were processed using Pearson's chi-squared test at the first stage (to identify differences), high-quality content analysis at the second stage and Mann - Whitney $U$-test for independent samples at the third stage (to identify differences).

\section{Results}

The auxiliary (first) stage of the study. Significant differences were identified with respect to all three considered behavioural social maturity criteria. Thus, sample analyses of 1994, 2000, 2005, 2010, and 2015 showed significant differences $\left(\chi^{2}=27.761 ; p=0.000\right)$ in the respondents' answers about their marital status (see Figure 1): the respondents of the older generation have a significantly higher percentage $(30.8 \%)$ of the answers "I am in a registered marriage" as compared to the younger generation $(4.2 \%)$. There is a tendency for an increasing number of answers "We live together but do not register our marriage" from 2000 (4.8\% of the respondents born in 1980) till 2015 (13.2\% of the respondents born in 1995).

Significant differences were revealed $\left(\chi^{2}=16.229 ; p=0.000\right)$ in the answers of respondents born in 1979 and 1990 to the question about the presence of children (see Figure 2). Thus, more than a half (54.7\%) of the respondents born in 1979 answered this question positively at the age of 25 , and the percentage of positive answers for respondents born in 1990 was much lower $-36.5 \%$.

Significant differences were revealed $\left(\chi^{2}=14.789 ; p=0.001\right)$ in the answers of the respondents of the older and younger generations to the question "Does your work ensure your financial independence?". The percentage of the respondents of the younger generation (26.1\%) who answered positively to this question is much lower as compared to that of the respondents of the older generation (43.4\%) (the answers of the millennials were compared with the answers of the Gen Xers given more than 15 years ago).

The confirmed differences between the generations in all the three criteria of compliance with the standards of social maturity allowed us to move from the auxi- 
liary stage to the main one, i.e. a discussion of the social-psychological characteristics of the perception of these differences and values that accompany them.

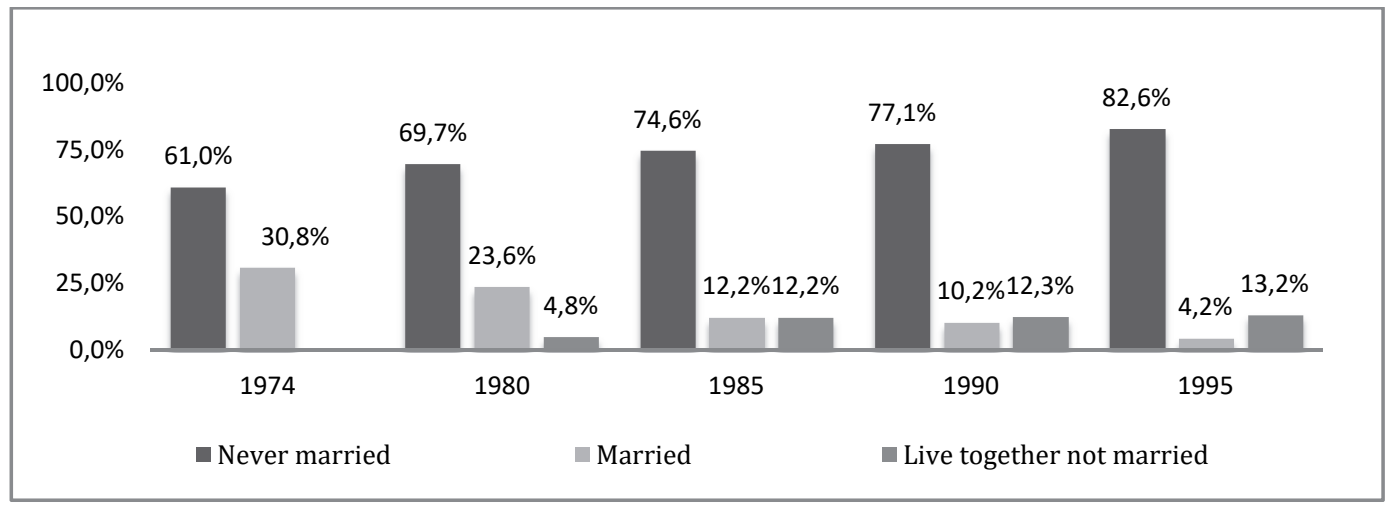

Figure 1. The marital status of 20 -year-old Russians born in different years (years of birth are shown on the horizontal axis)

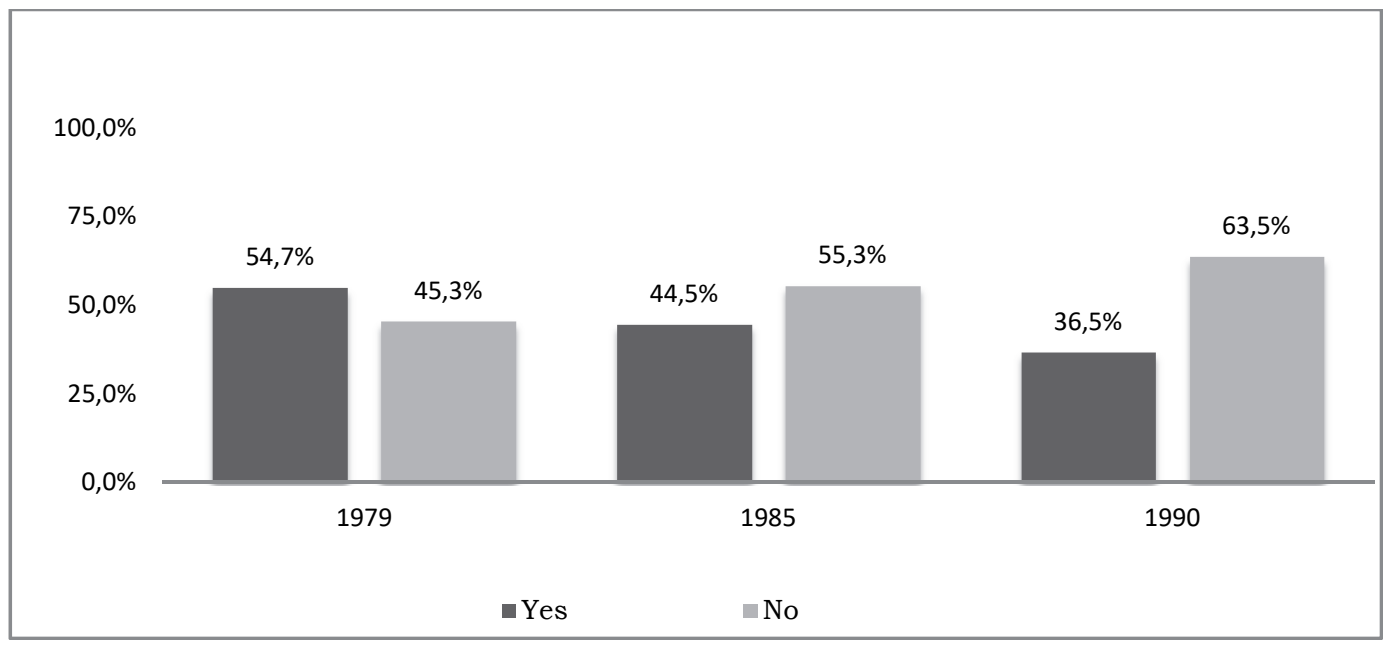

Figure 2. The presence of children among 25-year-old Russians born in different years (years of birth are shown on the horizontal axis)

The main (second and third) stage of the study. Within the second (qualitative) stage, we analysed the interviews of members of the two generations (X and $\mathrm{Y}$ ). In interviews with the majority of Gen $X$ respondents, there were phrases denoting their perception of the generational differences from the younger generation: "Well, they began to live differently - this is also good", "But still, there was another life", etc. The older generation generally does not condemn the tendency of young people toward later marriage, birth of children and entry into working life: "Actually, I don't care", "I neither reproach nor support them", "And when she is 16 and she is told 'go get married', it is as if we are in Central Asia: I can't understand it. She still wants to live for herself..."). However, there are also negative assessments as to: (a) the increased number of civil marriages: "Well, it's not good, because it's not responsible", "To get married and keep house together, one should have the guts. This is also selfishness in addition"; (b) unwillingness to have children: "I think that sooner or later a woman will want her own nest and her children. 
Or what is the point in this existence, in this life?"; (c) trend toward a later entry into working life: "Yes, idler. Or spoiled", "Well, that is, those who are freeloading off their parents do not think about anything, wasting their lives". Speaking about the possible reasons for such trends, the respondents of the older generation mention: (a) the priority of a career and the desire to earn more money, receiving higher education by modern young people, including the need to obtain knowledge "because of technological progress" ( "And the fact they have children later, perhaps, it's because nowadays many of them are getting higher education, making a career"); (b) the positive economic changes, thanks to which parents have the opportunity to financially support their adult children ("Well, because before, actually, there was neither money nor food. And people tried their best to survive faster, faster, faster"); (c) the growing needs and opportunities of modern young people and a more favourable economic situation in the country ("Yes, it's all about finances. Then people probably became more interested in living. They want something more than just washing their pants", "We had fewer needs before, there was no such purpose as to earn money, and then only to have a child"); (d) the propaganda of the consumer lifestyle and hedonistic values ("No one says: "Take a loan, buy a pushchair, give birth to a child'. Everyone says: 'Buy yourself a car, a ticket to the Maldives" "). In addition, the economic difficulties for creating a family were noted ("The state does not support young families, either").

At the same time, members of the older generation recognise marriage, the presence of children and employment as maturity criteria. For example, many respondents describe a working woman (even without a husband and children) as a mature person ("Well, without a family. So she must be looking for a man, she hasn't found one yet - she's looking for a life partner - if he's not there, then where is he to be found? "). Many respondents consider marriage registration an important and serious step, and reluctance to enter into official relations and have children as a desire to avoid responsibility ("not planning a serious life", "not good, because it's not responsible"), which is also explained by personal qualities ("This is selfishness in addition"), the immaturity of a person ("They have not grown yet", "But she does not need a family. Psychologically, she has not yet come to this ") and hedonistic values ("They live for their own pleasure", "fixated on earning income, enjoying prosperity", "travelling, living for themselves, having fun"). The respondents also emphasised the importance of personal maturity for creating a family ("First you should represent yourself as a personality. Now, I am ready to work, I am ready to get married, I am ready to give birth to children"). It is noteworthy that the majority of the respondents interpret a woman's having a child at such a young age as an accident, rather than a conscious decision ("Because she 'got knocked up', of course”).

Most millennials, like the members of the older generation, reflect upon the very fact of the differences between their generation and the changing conditions of the surrounding reality as compared to the conditions in which their parents lived: "They have grown old and do not follow the fashion. In our time, a man without education is a man without a future, he will remain a locksmith for life"; "They are not fixated to the fact that one needs to buy an apartment, register a marriage; they are kind of modern, so to say. Well, now I think a lot of couples 
live like that and it's normal for them". In general, the representatives of the younger generation are more positive about the tendency toward later marriage and the birth of children in comparison with the older generation: "Perhaps this is even more correct"; "There will be fewer couples who have children through carelessness or to be like everyone else so as not to be different". The reasons for the trend to start a career later, according to the younger generation, are as follows: (a) the changed hierarchy of values; (b) the increased terms of studies due to higher education ("Because education has lengthened in terms, and with full-time study it is impossible to do everything well"); (c) the immaturity and unwillingness to start a family ("I think that, if people are ready to start a family, let them do so, but there are fewer such people"). At the same time, the younger generation often speaks of achieving a certain level of self-development and self-realisation as the needs of the modern young generation ("Perhaps people now want to devote themselves more to developing their own personalities rather than to starting and supporting a family as a unit of society") and as a necessary factor for starting a family that is not noted by the members of the older generation ("Indeed, I think that a family needs to be started when you yourself are mentally and financially prepared to provide your family and raise a child. That is, you need to develop yourself to a certain level"). Far more respondents of the younger generation, as compared to the older generation, note the importance of financial security for creating a family ("They are not yet well-off enough to start a family. Therefore, they are earning money"). The reasons for the trend towards a later start of family and working life also include the improvement of economic and social conditions and the resulting increase in the needs of young people ("And you think: 'don't want to enclose myself in an apartment with my husband and child, I want to go now and see the world. Why shouldn't I?' ", "And education was different before, there was no choice: work and the only alternative to work is family"). One can also note such personal characteristics of modern youth as individualism ("Well, in principle, people now don't see value in marriage, we seem to have a sort of individualistic culture rather than familial or collectivistic") and the spread of hedonistic values ("Everyone wants to live well, live with pleasure"). It is curious that often the respondents blame the parent generation for this trend because of hypercustodial behaviour towards children ("Parents treat children like children much longer", "I think parents cared for him too much").

The perception of the above maturity criteria by the younger generation is different from that of the older generation. Most respondents give a positive assessment to the couple, who do not seek to register their relationship, saying that in the modern world this is a normal model of behaviour, explaining their position by the fact that marriage now "does not matter at all". The younger generation perceives such people as having hedonistic value orientations ("They probably feel comfortable this way - not to change anything, but just have fun together"), striving for self-realisation and financial solvency ("They are not yet well-off to start a family"). The unwillingness to have children is perceived by the respondents of the younger generation as a desire to avoid responsibility ("They don't want to burden themselves with children") and immaturity ("That is, they live for themselves. Maybe even with some kind of infantilism, as it were"). That is, nega- 
tive assessments of situations that demonstrate immature behaviour according to the criteria of marriage and the presence of children are practically not found in the younger generation.

The criterion of working life is also perceived by the younger generation differently than by the older one. Half of the respondents rated a non-working student as immature ("Dependent", "Looking like some kind of infantile"). However, the explanation of such a lifestyle is different from that of the older generation: the younger generation is less likely to attribute negative personal qualities to such a person, more often they say that the reasons are the family's well-being and (as mentioned above) hyper-care ("Perhaps, the parents insist on this way of life"). The perception of the younger generation of a situation that demonstrates the standards of the older generation in "mature" behaviour is mainly based on negative assessments ("It seems like I should pop a kid so as not to be different?", "Call this a hunch but they somehow rushed into it").

The third (quantitative) stage of the study. The revealed difference in relation to social maturity criteria was interpreted using the analysis of the third (quantitative) stage of the study, which was focused on the values of millennials and the perception of these values by Gen Xers. Thus, the following criteria are rated by the millennials higher as compared to the Gen Xers: 'Pleasures' $(\mu=62.7)$ (fourth place vs. ninth place), 'Diversity' $(\mu=62.7)$ (third place vs. sixteenth place), 'Individuality' $(\mu=64.1)$ (second place vs. nineteenth place). The top five values according to the millennials also includes 'Knowledge' $(\mu=63.5)$ (according to the Gen Xers, it is ranked only thirtieth). In turn, 'Social Utility to Society' $(\mu=36.9)$ is ranked only seventeenth (but fifth, according to Gen X); 'Happy family life' is ranked sixteenth by the millennials $(\mu=37.4)$ (whereas it is ranked tenth, according to Gen Xers).

Gen Y values (according to Rokeach Value Survey) as perceived by millennials themselves and by Gen Xers

\begin{tabular}{ccc}
\hline Rank & Gen $\mathbf{Y}$ values (self-perceived) & Gen Y values (perceived by Gen X) \\
\hline 1 & Comfortable life & Comfortable life \\
\hline 2 & Pleasure & Pleasure \\
\hline 3 & Inner harmony & Interesting job \\
\hline 4 & Self-development & True friendship \\
\hline 5 & Social recognition & Health \\
\hline
\end{tabular}

Answering the question "What values do you think are characteristic of millennials?", the Gen Xers ascribe to them the desire for a 'Comfortable life' (first place), 'Pleasures' (second place), 'Interesting work' (third place). The millennials perceive themselves in a similar way: when they answer the question "What values do you think are characteristic of Gen Xers?", they also mention 'Comfortable life' (first place) and 'Pleasures' (second place), adding 'Development' and 'Public recognition' (fourth place) and (fifth place) respectively (see Table). 


\section{Discussion}

The data obtained at the third stage indicate that there exists a certain value gap between the generations under study, which was confirmed in a number of previous works (Yemelyanova, 2019; Martsinkovskaya, Poleva, 2017; Rean, Shagalov, 2018; Omelchenko, 2012). The results can be combined and, as a result, we can note that millennials are characterised by a shift in values towards individualistic ones associated with hedonism and self-development and, accordingly, indicate a certain rejection of conditionally collectivistic values, a decrease in the significance of family values, which was also confirmed in a number of earlier studies (Radaev, 2019; Khriptovich, 2015; Billari, Liefbroer, 2010).

In this context, it is curious enough that the perception of the millennials by themselves and the perception of the millennials by the Gen Xers is in logical consonance (both the Gen Xers and the millennials see the latter as an individualistic generation, striving for self-realisation and hedonism). But at the same time, the factor of well-being ('Money'), the importance of which both generations attribute to the millennials (first place), in fact, does not find a place even in the top 'five' of their values. The Gen Xers do not blame the millennials for their individuality and changing the social maturity criteria, find excuses for them in the changed social context (e.g. desire to make a career, receive an education; positive trends in the economy, the cult of consumption) and, as a result, in the values of millenials; but nevertheless, they think of the younger generation as less mature, and often as trying to avoid responsibility (if they do not want to have children and start a family).

In the perception of the millennials, the changed social context is not something that has to be accepted as a forced necessity but rather as new positive trends. Instead of the familial and collectivistic values, which seem to be closely related to marriage and children, there come individualistic values, where the leading positions are held by the values of self-development ('Cognition', 'Education') and hedonism ('Pleasure', 'Diversity'). Similar results were obtained earlier in the Western studies (Bruce, Kelly, 2013). Perhaps, this 'tandem' of self-development and hedonism explains the later start of the millennials in terms of making a career and gaining financial independence and, accordingly, the low value of 'Money' (contrary to the stereotypes of the Gen Xers and the autostereotypes of the millennials themselves). The low importance of financial achievements is easily explained by the relative economic prosperity, under which this generation socialised, as well as the primacy of the values of self-development, which are higher than the values of material wealth. Moreover, it is possible, in the eyes of other generations, the desire for hedonism is erroneously associated with the desire for financial savings, which gives rise to such erroneous stereotypes. These data are consistent with the previously obtained results (Rean, Shagalov, 2018), in which the younger generation appreciates pleasure and freedom, but does not tend to separate financially from adults, thereby offering, in fact, new social maturity criteria.

The results obtained on a sample of modern Russian millennials generally correspond to similar trends in this generation identified in a number of Western studies (Billari, Liefbroer, 2010; Lusk, 2007; Twenge, Campbell, 2009): changes in the social maturity criteria and stereotypes about infantilisation of millennials (Arnett, 2000), apparently, are part of the global psychological portrait of the modern 
millennials, and there is no need to talk about the same values behind this portrait: the different cultural and historical context of the socialisation of these generations in different countries naturally introduces differences in their value orientations.

\section{Conclusion}

So, the conducted quantitative and qualitative research allows us to conclude:

1) both generations recognise the existence of intergenerational differences, the main of which (in the context of this study) is in the perception of social maturity criteria;

2) the Gen Xers perceive marital cohabitation, having children and financial independence as attributes of entry into adulthood, which for a number of reasons, the millennials decided to reject;

3) the millennials recognise the rejection of the previously existing criteria of social maturity and not only justify them but perceive them as a whole much more positively;

4) the absence of early marriages and the later birth of children for the millennials is a conscious choice, and they find the reasons for such behaviour in the great opportunities that society gives them, which, among other things, allow them to better prepare for family life. In addition to the influence of society, some of the millennials tend to blame the previous generation for hyper-custody, which allowed them to alienate the classic standards of 'adult' behaviour;

5) modern Russian millennials in general reproduce similar trends (in relation to social maturity) inherent in this generation in the West;

6) the Generations $\mathrm{X}$ and $\mathrm{Y}$ treat and interpret changes in the perception of social maturity criteria in a similar way; the Gen Xers are relatively tolerant of these changes;

7) the general consensus in the mutual and individual perceptions of values by the Gen Xers and millennials, the tolerance of the older generation to the younger one in terms of accepting these changes against the backdrop of serious value dissonance between the two generations allows us to make a positive forecast for productive and effective communication and interaction between these cohorts.

However, the study has a number of limitations, the main of which are the following:

1) the study allows us to talk about the differences of generations in terms of attitude to maturity only in terms of perception of values in the context of social criteria but we cannot analyse the deeper psychological mechanisms of growing up, which does not reduce its value;

2) the study did not provide a distinction between generational and age-related factors by measuring the characteristics of identification with a particular generation. At the same time, the cohort analysis performed at the first stage partly allows us to remove this limitation;

3 ) the study did not consider gender differences between generations, which is a prospect for further research.

\section{References}

Andreeva, G.M. (2001). Sotsial'naya Psikhologiya. Moscow: Aspekt Press Publ. (In Russ.)

Anisimov, A.I., \& Kireeva, N.N. (2010). The problem of socially-psychological research of occupational health of personality. Scientific Notes Journal of Saint Petersburg State Institute of Psychology and Social Work, (1), 73-79. (In Russ.) 
Arnett, J.J. (2000). Emerging adulthood: A theory of development from the late teens through the twenties. American Psychologist, 55(5), 469-480.

Becton, J., Walker, H., \& Jones-Farmer, A. (2014). Generational differences in workplace behaviour. Journal of Applied Social Psychology, 44, 175-189.

Billari, F.C., \& Liefbroer, A.C. (2010). Towards a new pattern of transition to adulthood? Advances in Life Course Research, 15(2), 59-75. https://doi.org/10.1016/j.alcr.2010.10.003

Bruce, M., \& Kelly, S. (2013). Expectations, identity and affordability: The housing dreams of Australia's Generation Y. Housing, Theory and Society, 30(4), 416-432. http://dx.doi.org/10.1080/14036096.2013.767279

Calcutt, A. (2010). Arrested Development: Pop Culture and the Erosion of Adulthood. London: Cassell.

Costanza, D.P., Badger, J.M., Fraser, R.L., Severt, J.B., \& Gade, P.A. (2012). Generational differences in work-related attitudes: A meta-analysis. Journal of Business Psychology, 27, 375-394. https://doi.org/10.1007/s10869-012-9259-4

Egri, C.P., \& Ralston, D.A. (2004). Generation cohorts and personal values: a comparison of China and the Unites States. Organization Science, 15(2), 210-220.

Gilleard, C., \& Higgs, P. (2005). Contexts of Ageing: Class, cohort and community. Cambridge: Polity Press. https://doi.org/10.1017/s0144686x06264894

Hershatter, A., \& Epstein, M. (2010). Millennials and the world of work: An organization and management perspective. Journal of Business and Psychology, (25), 211-223. https://doi.org/10.1007/s10869-010-9160-y

Ilyin, E.P. (2012) Psikhologiya Vzrosleniya. Saint Petersburg: Piter (In Russ.)

Khriptovich, V.A. (2015). Pokolenie infantil'nykh: Obzor problemy. Nauchnye Trudy Respublikanskogo Instituta Vysshei Shkoly, (15), 206-213. (In Russ.)

Kon, I.S. (1999). Sotsiologicheskaya Psikhologiya. Moscow: NPO MODEK Publ. (In Russ.)

Levada, Yu.A. (2011). Selected Works, 2000-2005. Moscow: E.V. Karpov Publ. (In Russ.)

Lusk, B. (2007). Study finds kids take longer to reach adulthood. Provo Daily Herald. Retrieved June 15, 2020, from https://www.heraldextra.com/news/article_3db6743c-35bc5e6a-a737-938b93f57ac3.html

Lyons, S.T., \& Kuron, L.K.J. (2014). Generational differences in the workplace: A review of evidence and directions for future research. Journal of Organizational Behavior, (35), 139-157. https://doi.org/10.1002/job.1913

Mannheim, K. (1997). Essays on the Sociology of Knowledge. London: Routledge.

Martsinkovskaya, T.D., \& Poleva N.S. (2017). Pokoleniya epokhi tranzitivnosti: Tsennosti, identichnost', obshchenie. Mir Psikhologii, (1), 24-37. (In Russ.)

Omelchenko, E. (2012). Russian youth from the 1990s until 2010s: Generational changes. In Generation X Goes Global: Mapping a Youth Culture in Motion (pp. 248-267). NY: Routledge.

Parry, E., \& Urwin, P. (2010). Generational difference in work values: A review of theory and evidence. International Journal of Management Reviews, (13), 79-96. https://doi.org/10.1111/j.1468-2370.2010.00285.x

Patturina, N.P (2006). Maturity in modern psychology. Iizvestia: Herzen University Journal of Humanities \& Sciences, (17), 113-126. (In Russ.)

Pishchik, V.I. (2015). Preemstvennost' i izmenenie obshchikh chert pokolenii, sopryazhennykh s ikh mental'nost'yu. In: L.I. Ryumshina (Ed.), Prikladnaya Psikhologiya Obshcheniya $i$ Mezhlichnostnogo Poznaniya (pp. 20-30). Moscow: KREDO Publ. (In Russ.)

Radaev, V.V. (2019). Millenialy. Kak Menyaetsya Rossiiskoe Obshchestvo. Moscow: HSE Publ. (In Russ.)

Rean, A.A., \& Shagalov, I.L. (2018). Personal values as predictors for experiencing happiness in adolescents. Voprosy Psikhologii, (6), 16-28. (In Russ.)

Rikel, A.M. (2019). Generation as a social-psychological research object: Playing at home or an away match? Social Psychology and Society, 10(2), 9-18. https://doi.org/10.17759/sps.2019100202 (In Russ.)

Rikel, A.M., \& Dorenskaya, S.V. (2017). A socio-psychological model of values among different generions in modern Russian society. Russian Psychological Journal, 14(4), 205-225. https://doi.org/10.21702/rpj.2017.4.10 (In Russ.) 
Russian Monitoring of the Economic Situation and Public Health, RLMS-HSE. Retrieved June 15, 2020, from http://www.hse.ru/rlms (In Russ.)

Semenova, V.V. (2003). Sovremennye kontseptual'nye i empiricheskie podkhody k ponyatiyu "pokolenie". In L.M. Drobizheva (Ed.), Rossiya Reformiruyushchayasya (pp. 213-237). Moscow: Institut sotsiologii RAN Publ. (In Russ.)

Shevchenko, D.A. (2013). The study of consumer behavior of large segments of the market in Russia: Generational approach. Practical Marketing, (4), 4-13. (In Russ.)

Starchikova, M.V. (2012). Mezhpokolennoe vzaimodeistvie v sovremennoi Rossii. Sociological Studies, (5), 140a-144. (In Russ.)

Strauss, W., \& Howe, N. (1991). Generations: The History of America's Future 1584 to 2069. New York: William Morrow.

Twenge, J.M., \& Campbell, S.M. (2009). Generational differences in psychological traits and their impact on the workplace. Journal of Managerial Psychology, (23), 862-877. https://doi.org/10.1108/02683940810904367

Yemelyanova, T.P. (2019). Kollektivnaya Pamyat' o Sobytiyakh Otechestvennoi Istorii: Sotsial'noPsikhologicheskii Podkhod. Moscow: Institut psikhologii RAN Publ. (In Russ.)

Article history:

Received: 12 June 2020

Revised: 6 July 2020

Accepted: 15 July 2020

\title{
For citation:
}

Rikel, A.M. (2020). Perception of Social Maturity Criteria, Self-perception and Value Orientations among Russian Millennials. RUDN Journal of Psychology and Pedagogics, 17(3), 491-503. http://dx.doi.org/10.22363/2313-1683-2020-17-3-491-503

\section{Bio note:}

Alexander M. Rikel, Ph.D. in Psychology, is Associate Professor at the Social Psychology Deartment, Faculty of Psychology, Lomonosov Moscow State University (Moscow, Russia). ORCID iD: https://orcid.org/0000-0002-6940-4244. E-mail: a.m.rikel@gmail.com

Исследовательская статья

\section{Восприятие критериев социальной зрелости, самовосприятие и ценностные ориентации представителей российского поколения «Игрек»}

\author{
А.М. Рикель \\ Московский государственный университет имени М.В. Ломоносова \\ Российская Федерация, 119991, Москва, Ленинские горы, 1
}

Аннотация. В современном мире разница между поколениями становится все более очевидной. Все чаще отмечается нарушение межпоколенной трансмиссии ценностей, все больше выделяется различий между поколениями. Изучаются особенности, отличающие современные поколения друг от друга, ценности поколений, а также восприятие этих ценностей как конкретным поколением, так и представителями взаимодействующих 
с ним когорт. Некоторые исследователи отмечают, что современному молодому поколению (так называемому поколению «Игрек») в сравнении с их родителями (так называемым поколением «Икс») свойственен отказ от принятых ранее критериев социальной зрелости (которую можно понимать как соответствие ряду социально-психологических стандартов), однако исследования, затрагивающие данную тему, практически отсутствуют. Было проведено трехэтапное (количественное и качественное) исследование (первый этап, $\mathrm{N}=349$ чел.; второй этап $\mathrm{N}=25$ чел.; третий этап $\mathrm{N}=100$ чел.). На первом этапе использовались и анализировались данные лонгитюдного обследования домохозяйств РМЭЗ НИУ ВШЭ; на втором - проводилась серия полуструктурированных интервью по теме восприятия социальной зрелости; на третьем - исследовались ценности поколенческих когорт с помощью методики «Ценностные ориентации» М. Рокича и авторской анкеты, позволяющей оценить влияние культурного контекста на формирование ценностей. В рамках первого (вспомогательного) этапа подтвердилась базовая гипотеза о различиях в соответствии социальным критериям зрелости (возраст вступления в брак, появления детей в семье, обретения финансовой независимости) у молодого («Игрек») и старшего («Икс») поколений современных россиян. В рамках второго этапа были выявлены особенности восприятия данных различий, а с помощью результатов третьего этапа была предложена интерпретация полученных различий с помощью выявленных у поколения «Игрек» ценностей и особенностей восприятия этих ценностей им самим и поколением «Икс».

Ключевые слова: поколение «Игрек», поколение «Икс», ценности поколения, социальная зрелость, критерии социальной зрелости

\section{История статьи:}

Поступила в редакцию: 12 июня 2020 г.

Принята к печати: 15 июля 2020 г.

\section{Для цитирования:}

Rikel A.M. Perception of social maturity criteria, self-perception and value orientations among Russian millennials // Вестник Российского университета дружбы народов. Серия: Психология и педагогика. 2020. Т. 17. № 3. С. 491-503. http://dx.doi.org/10.22363/23131683-2020-17-3-491-503

\section{Сведения об авторе:}

Рикель Александр Маркович, кандидат психологических наук, доцент кафедры социальной психологии факультета психологии, Московский государственный университет имени М.B. Ломоносова (Москва, Россия). ORCID iD: https://orcid.org/00000002-6940-4244. E-mail: a.m.rikel@gmail.com 